Article

\title{
Sin and Addiction: Conceptual Enemies or Fellow Travelers?
}

\section{Linda Mercadante}

Straker Professor of Historical Theology, The Methodist Theological School in Ohio, 3081 Columbus Pike, Delaware, Ohio 43015, USA; E-Mail: LMercadante@mtso.edu; Tel.: +1-740-362-3442

Academic Editors: Chris Cook and Wendy Dossett

Received: 26 December 2014 / Accepted: 29 April 2015 / Published: 11 May 2015

\begin{abstract}
The addiction recovery metaphor of Alcoholics Anonymous (AA) and the $\sin$ /salvation metaphor of Protestant heritage have a lot more in common than people realize. On the surface, of course, it seems that the addiction recovery process is quite the opposite of what is assumed to be a religious approach to addiction. Many assume that religion takes a moralistic or judgmental attitude to addiction, focusing on intentional wrong-doing, lack of will power, or sin, i.e., offending God, self and others. Instead, from a theological perspective, sin and addiction are not the opposites generally assumed. The identification of alienation from God, and the focus on spirituality and healing are core issues for both concepts. Understanding this congruence can facilitate a very productive conversation between theologians, religious believers, and recovering persons. ${ }^{1}$
\end{abstract}

Keywords: addiction recovery; theology; sin; spirituality; Oxford Group; religion; Protestant; will power; disease; moralism

\section{Popular Assumptions Need More Clarity}

While it is generally known that the founders of Alcoholics Anonymous (AA) had gotten their start in recovery through the evangelistic, Christian-oriented Oxford Group, a fact explicitly acknowledged by scholars, many rank-and-file members are mostly unaware of the large debt owed there. Instead, it is assumed that early AA worked hard to distance itself from these roots. It is often said that early AA made itself more generic so that a broader range of people with alcohol problems - whether religious or not - could feel comfortable there and benefit from the program without having to claim a Christian

\footnotetext{
1 For more information and qualitative research on this connection, see [1].
} 
conversion experience. However, that is only part of the story. For many things were borrowed, many undercurrents remain, and many debts are still owed to AA's Christian roots.

Yet in spite of AA's Oxford Group historical roots and the two groups' theological interdependence - both of which we will shortly examine - often popular conviction sees only two ways to understand alcohol and other addictions - either as a failure of willpower and morality, or as a disease process. Many assume that the more contemporary, humane attitude is to see addiction as disease, with the older, out-moded approach to see it as sin. Considering addiction as a spiritual disease does help nuance and partly overcome the dichotomy between sin and addiction. Nevertheless, it is important to acknowledge the theological contribution that Oxford Group ideas lent to AA understanding. This borrowing can help people trapped in addiction - and those treating them - avoid the twin pitfalls of excessively blaming the afflicted ones for their condition, or largely seeing them as victims of circumstances beyond their control [2].

This is not, however, to claim some kind of covert Christian evangelical agenda for AA. Instead, as we will see, knowing the roots and debts that AA owes to the Oxford Group can help us better understand how AA works and why it still resonates with many in the U.S., even as we grow further away from our historic Protestant roots. More clarity is achieved if we are aware of AA's continued use of a distinct theological framework, even if this framework is routinely unacknowledged [3].

\section{AA's Roots in the Oxford Group}

A brief look at history reveals that the 12 Step model came by these borrowings honestly. Before founding AA, Dr. Bob and Bill Wilson, as well as many of the early members, found their initial help through the popular Christian evangelistic movement known as The Oxford Group. The Oxford Group was a "parachurch," or independent, evangelistic religious movement that began its existence as the "First Century Christian Fellowship" in 1921, was renamed the Oxford Group in 1931, flourished in the 1930s and then declined around World War II, emerging afterward as "Moral Rearmament." In spite of its name, this was primarily an American phenomenon that worked alongside, although kept its distance from, organized Christianity [4]. Many recovering persons from that period were quite frank in admitting they owed their initial sobriety to this Group. While the Group took addiction seriously and focused significant attention on alcoholics, they saw these problems as only one version of humans' perennial tendency to turn away from God. In other words, sin.

In their attitude toward human dysfunction, the Oxford Group was more of a throwback to earlier ideas of sin and conversion. Earlier theological themes regarding sin focused on such factors as turning away from God, disobeying God's will, self-centeredness, etc., focusing on the individual. The Oxford Group approach seemed to echo earlier ideas in that it implicitly went against the early twentieth century mainline Christian emphasis on "the social gospel" which paid more attention to systemic and societal problems than to individual wrongdoing. Thus, similar to nineteenth century theology and revivalism, the Oxford Group privatized morality, seeing individual choices, rather than social problems, as the proper focus for their efforts.

The Oxford Group was founded by Lutheran minister Frank Buchman. Although ordained, he did not pastor a church but instead focused his efforts on a ministry of personal evangelism, first with college students and then with the "up and outers" rather than the "down and outers." By conducting elaborate 
"house parties," he and his trained helpers "came alongside" invited guests. Their goal was to lead them to realize and then confess their personal failings and pray for God's help in restoring them to spiritual health. Buchman stressed theological simplicity and showed little interest in the intellectual life. He reduced his theology to just a few simple concepts: All people are sinners. All sinners can be changed. Confession is prerequisite to change. Changed persons can access God directly. Miracles are again possible. And changed persons must change others [5].

Although the key concepts held by the Oxford Group were traditional, their methods and language were deliberately contemporary. Instead of tent revivals and altar calls, they worked through personal invitation, small-group sharing, confession and hearing the stories of "changed" persons. Medical terminology was often used, rather than traditional sin and conversion language. For the Group, guests were often referred to as "patients" and their problems as "disease." They spoke of the need to make a "spiritual diagnosis" and called their method "soul surgery" (e.g., see [6]).

However, just like earlier frontier revivalists, the Oxford Group was interested in awakening a sense of sin, prompting a desire for conversion, and getting people to turn their lives over to God. The Group did not focus on the social issues, which might push individuals into dysfunctional behavior or hamper their growth. Instead, they were convinced that all problems and all change happens from the individual outward. Buchman taught that sin was anything that stood between the individual and God, with the key sin being selfishness or self-centeredness. This is consistent with the theological idea that inordinate self-centeredness leads to alienation from God, which is one core definition of sin. Problematic behavior, then, is a symptom of this alienation rather than the core of sin. For the Group, however, sin was primarily an offense against the self because it frustrated the realization of one's God-directed potential, a rather modern gloss on the traditional definition of sin (see, e.g., [7]).

The Group had high expectations from "changed" persons, expecting the four "absolutes" of absolute honesty, absolute purity, absolute unselfishness, and absolute love. These absolutes would later cause early AAs sufficient discomfort that they were not made part of the new program. The Oxford Group also had four requirements for attaining these absolutes. These included sharing (including confession and witness), surrendering to God, making restitution, and following divine guidance. Thus the Group practiced a form of ethical and religious perfectionism that could be reduced to a call for renewed morality. Key to the whole program was submission to God in all things, as this alone gave the person the power that undergirded subsequent and successful human effort. "It Works" was a phrase frequently heard in Oxford Group testimonials. Once a person was changed, it was expected that problems of every sort would simply disappear. Now, it was said, they knew the secret of real happiness and, in fact, had become sane. The Group prided itself on being available at any time to help the troubled. They insisted that no one had ever sunk too low for their efforts. They declared that only a simple wish to change was necessary for the work to begin. They expected the conversion process to happen in stages, known as the "five Cs," that is, confidence, conviction, confession, conversion, and continuance. Key to the whole process was their insistence that only by passing on their experience to others would they be able to maintain their spiritual sanity (see, e.g., [8-10]).

The similarities between many of these facets and the AA approach are obvious. In addition to many parallels of method, such as personal attention and a step-by-step approach, there are also many conceptual similarities. These include reframing the problem in medical terms, seeing "self-will run riot" 
as the core problem, recognizing a Higher Power and giving one's will over, making amends, and others. A closer theological analysis of these features will follow in the next section.

Given the many similarities, it is clear that Bill Wilson, Dr. Bob and some others of the Oxford Group "alcoholic squadron," gained much from their Oxford Group experience. Eventually, however, they left the Group when their desire to focus only on alcoholics was seen by the Group as too narrow. Early AAs did not want to focus on evangelism, as the Oxford Group did. In addition, they hoped this new group could appeal to a wide diversity of people with varying religious (or non-religious) backgrounds, rather than the Oxford Group's natural affinity for Protestants. In the process, they also made many practical adjustments. For instance, they gave up the intense method of pressuring prospects to locate and repent of their personal failings, since they found alcoholics did not respond well to it. They gave up "team guidance" as too authoritarian. They gave up the Oxford Group's fondness for publicly identifying its converts and instead insured anonymity. While retaining the confidence that alcoholism was a spiritual problem, they toned down the Group's religious language. Rather than just one more example of the human tendency to sin, i.e., turn away from God, early AA understood alcoholics and their problem as different and distinctive. In addition, these early AA members had a growing awareness that the Oxford Group's perfectionistic expectations (the "absolutes") and overly optimistic view of conversionary change - the Group routinely expected dramatic and speedy results — did not suit very well persons suffering from alcohol addiction.

\section{Addiction Model and Doctrine of Sin}

In order to understand how the addiction recovery metaphor works "theologically," we need to briefly analyze it. Much of my analysis comes from a close reading of the Big Book of Alcoholics Anonymous [11]. While today conversation in meetings can go in many different directions, it is still true that the Big Book forms the foundation for the 12 Step approach to addiction recovery. The Big Book shows some distinct similarities with the Oxford Group ethos. While the borrowed methods are well worth analyzing, they are not the prime focus here. Instead, we will largely focus on the theological aspects that were borrowed and which were adjusted to better suit persons suffering from alcohol addiction. It is not the adjustments that are startling, however, but the common under-themes. For in spite of early AA's modifications to the Oxford Group ethos, the many theological parallels with the Oxford Group are core to the 12 Step approach. Rather than a simple rejection of the sin concept in favor of a disease or illness metaphor, in fact, early AA kept much of the theological underpinnings, but changed some of the process, the expectations, and the language.

The early "alcoholic squadron" of the Oxford Group were all very familiar with the word "sin."[12]. Of course, the word "sin" is only rarely used in the Big Book and is today often anathema in meetings. But that is only the surface story. For if anything, early AA was more focused on sin's hold than the Oxford Group, for they had found that alcoholism was more intransigent than many realized. In fact, early AA did not simply rest upon a medical, illness or allergy view of alcohol addiction. Instead, similar to the sin concept they heard in the Oxford Group, early AA presents the alcoholic as having a spiritual illness that in some important ways lies behind the physical illness of alcoholism. The over-dominance of self is prominent for both groups and both groups use disease language to describe this problem. 
Neither group shies away from pushing members to realize the severity of their problems. For both groups, it is a problem of self-will versus God's will. Both groups urge a complete surrender of the self to God. Both believe that the will, in many respects, is still functional. If it were not, the requisite self-initiated submission to God would not be possible. Both believe God's power is elicited by one's submission. Both groups seek a complete transformation (or conversion), with nothing less seen as effective. Both understand individuals to suffer from what the 12 Steps calls "defects of character" and both have a goal of "removing" them. Both groups restrict the diagnosis to individuals and do not spend time on the implicating factors of social conditions. Both offer fairly limited definitions of the Higher Power and its character. Yet both see a divine agent who is interested in exercising total control over an individual. And only recurring submission of the individual's will can sustain the reception of this divine power and change behavior.

It is also important to see what AA adjusted from the Oxford Group theological scenario to make it work better for persons suffering from alcohol addiction. Most significant here is the tension in the use of "self-will" as the core problem. While sometimes the Big Book seems to restrict the problem of "self will run riot" to alcoholics, there are also suggestions that while everyone has this weakness, for some reason, alcoholics fall into this trip especially hard. Therefore, although both groups see the problem as unitary in nature, for the Oxford Group is it universally evident and for AA it seems particularly manifest in alcoholics.

While the Oxford Group used "affinity" evangelistically, i.e., to pair up a "changed" member with a "guest" who had similar difficulties, AA elevated that to a philosophy. This tends to reduce the universal understanding of the human predicament to the unfortunate disability of a particular group. And yet, as noted above, there are some gestures toward the problem of self-will as the universal human dangerzone. It took the burgeoning recovery movement to expand this philosophy out to cover wider segments of the population. Thus, the contemporary spreading of the disease metaphor of addiction to cover "process" addictions and other problematic areas may reveal a popular impulse to replace a formerly widespread view of sin with something equally broad. This is perhaps a belated contribution from the Protestant-based Oxford Group theological heritage of the 12 Steps.

Also different is the attitude toward and definition of God and the reality of divine-human communication. For AA, the Higher Power is defined by the alcoholic and yet the afflicted one is expected to turn his or her life over to this self-defined Higher Power, creating a theological dilemma that many may not realize. However, this could be a reflection of Oxford Group roots and AA's adaptation of them. For the Oxford Group, there is a quite Protestant conception of a sovereign God to whom one must submit. This God is also defined as wanting to be fully involved in one's life, demonstrating this through the work of Christ. Perhaps because of this difference, AA does much less explicit seeking or discussion of "God's will" (even though prayer and meditation to improve one's conscious contact with one's Higher Power is advised) than did the Oxford Group. Advice-giving and cross-talk is limited in regular AA meetings, whereas in the Oxford Group members freely shared what they thought God's will was for each other.

The total break with sin, urged by the Oxford Group, was transformed into a total break with alcohol. The Oxford Group "absolutes" were reduced to the goal of total abstinence. Even so, a remnant of Oxford Group perfectionism remains, since the AA member is expected in Step Six to become "entirely ready to have God remove all these defects of character." Even so, "progress, not perfection" is counseled in 
meetings. Of course, there is no mention of Christ in the 12 Steps, although he was prominent for the Oxford Group. There is no savior and no salvific work external or prior to the initiatory action of the alcoholic, except perhaps that of the AA members who have come before you. While the Oxford Group, as a group based on Christian principles, did ultimately attribute all their success to the work of Christ, early AA more generically focused on the efficacy and work of "the program." "It works if you work it." And the attitude toward community is different, too. For, although group support is essential in AA, there is no transformation into a community through spiritual incorporation into divinity, a theme in mainstream Christianity and important to the Oxford Group. Although the concept of grace is not missing in AA's understanding of community, it is more implicit and less overtly connected to God, or to some form of "divine community," and much more open to individual interpretation.

AA also introduced a very different approach to the will. Rather than a will that is functional but misdirected, the group presented a will that was partly disabled by its vulnerability to alcohol. And this represents a crucial theological insight. For it moves AA away from the temptation of a moralistic, judgmental and perfectionistic understanding of the problem (that is, sin) and actually puts it more in line with biblical tradition. It echoes the "bondage of the will" so persuasively presented in Paul's letter to the Romans (7:14-25) where even the things Paul knows he should do he cannot do, because he is a slave to sin.

${ }^{14}$ We know that the law is spiritual; but I am unspiritual, sold as a slave to $\sin .{ }^{15} \mathrm{I}$ do not understand what I do. For what I want to do I do not do, but what I hate I do. ${ }^{16}$ And if I do what I do not want to do, I agree that the law is good. ${ }^{17}$ As it is, it is no longer I myself who do it, but it is sin living in me. ${ }^{18}$ For I know that good itself does not dwell in me, that is, in my sinful nature. ${ }^{[\mathrm{a}]}$ For I have the desire to do what is good, but I cannot carry it out. ${ }^{19}$ For I do not do the good I want to do, but the evil I do not want to do-this I keep on doing. ${ }^{20}$ Now if I do what I do not want to do, it is no longer I who do it, but it is sin living in me that does it. ${ }^{21}$ So I find this law at work: Although I want to do good, evil is right there with me. ${ }^{22}$ For in my inner being I delight in God's law; ${ }^{23}$ but I see another law at work in me, waging war against the law of my mind and making me a prisoner of the law of sin at work within me. ${ }^{24}$ What a wretched man I am! Who will rescue me from this body that is subject to death? ${ }^{25}$ Thanks be to God, who delivers me through Jesus Christ our Lord! [New International Version]

For AA, there is only a partial paralysis of the will. The status of the will, identified in AA, calls up some ancient theological battles, which might seem esoteric to most people, but when translated into contemporary terms, prove that some core human dilemmas never go away. For instance, can one lose one's salvation (Armininism) in the same way that one can lose one's sobriety? Are we able to choose recovery, or is our will in a bondage that can only be loosened with divine help (Augustinianism)? And if instead our will is neutral, thus free to pursue good or evil (Pelagianism), then why do we hesitate to say that persons struggling with addiction are fully responsible for their plight? Many of the quandaries present in addiction and recovery echo age-old human dilemmas which theology has observed and grappled with for a very long time. Clearly, a mutually beneficial conversation is in order between religious and recovering persons, ideally with special assistance from those who inhabit both categories. 
Most important for the theological/addiction recovery conversation is the suggestion that AA represents a critique of the Pelagianism that sometimes affects Protestant attitudes toward addiction.

Yet this move has also led in an unexpected direction, bringing back a concept of evil. While mainstream Protestantism derides a belief in a literal devil, it has concomitantly lost a way to conceptualize "evil forces." The addiction recovery model may unknowingly fight against this loss. Indeed, the popularity of calling many types of human dysfunction "addiction," may gain some of its popularity by explaining how dangerous substances or disordered processes can tempt and control. In this way, it offers an explanation and a warning to a contemporary culture interested in controlling as much of human life as possible. The AA model speaks to the hidden fears of powerlessness, disorder, and biological determinism in a world where science seems to have promised much but also delivered many dangerous and unintended consequences. This is a rethinking of my earlier concern that a flat reading of the AA insistence on alcoholism as 'disease' would promote more, rather than less, biological determinism. Now, however, I want to highlight the nuance that lies underneath the "disease" concept of addiction, especially as it is actively utilized by persons with significant recovery.

In effect, early AA actually took more seriously the nuances embedded in the concept of evil. For "moral evil," also known as sin, involves human cooperation, one's own, or that of another, implying that one can be a victim of another's sin. However, AA also implicitly considers the idea of "radical evil," i.e., non-moral evil, which cannot be clearly attributed to human wrongdoing. It did this by identifying a substance and disease process that is cunning, baffling, powerful and essentially without clear cause. In this way, it comes close to contemporary theological understandings of "radical evil" as the "surd" or unexplainable feature, which is unlinked to personal wrongdoing, yet exerts a powerful influence. AA does this by objectifying this foe and containing it in a physical substance. The substance is made to stand in for a diabolic power just waiting to ruin one's life if one succumbs to it. While alcohol is not identified as a universal diabolic power dangerous to everyone, persons with significant recovery may also find its power greatly reduced. It is nevertheless important to note that this highlighting of alcohol's power over those people who are susceptible effectively externalizes radical evil because although one may be vulnerable to it, there is a sure way to block it out (total abstinence). While alcohol is not identified as a universal diabolic power tempting all people (as proponents of Prohibition believed) - and while recovering persons may find its power greatly reduced as one progresses - this schema does function as a way to externalize evil in early recovery. And yet the ever-expanding addiction metaphor skates close to re-introducing a more universal human vulnerability to radical evil by showing how addiction can come along even with necessary substances (e.g., food) and processes (e.g., sex, emotions, human dependencies). Therefore, the legendary battle between good and evil has been tamed and restricted. One still fights against it, but the battle is less cosmic and more earth-based.

While AA, like the Oxford Group, did offer help and hope for everyone, the Big Book makes clear that some unfortunates seem to be "constitutionally incapable of being honest with themselves."[13]. Ironically, this has theological echoes to "predestination," i.e., the conservative theological stance that not everyone is destined for salvation. Like the Oxford Group in its throw-back theology of sin, this similarity to predestination seems a throw-back to earlier views, even amidst a culture (and much of the church) which has roundly rejected any form of predestination. While any version of alcoholic "predestination" would likely have been far from the intentions of early AA — and would not be a modern scientific stance on the force of genetics - it is important we focus on popular usage. For some recovering 
persons, a kind of "genetic determinism" can be used to explain their own plight and also help explain the conundrum of those who never seem to "take" to the program.

Additionally ironic, are the theological undertones to the idea of "original sin." The idea of "original sin"-although wildly unpopular today — states that humans are born with a predilection to turn away from God and good. Today, for those who accept this view, original sin is more commonly thought to spring from being born into a "fallen" or warped world. Few modern proponents of original sin would agree with St. Augustine that this defect is passed along biologically. Yet many recovering persons assume that their genetic make-up has led them inexorably to their present plight. It is intriguing to hear distant echoes to this more strict view, then, when listening to the conversation of recovering persons.

However, against Augustine, this type of "original defect" is not universalized but often restricted to people with a family history of addiction. What is quite striking, however, is the way an AA approach to human vulnerability can lead to the uncoupling of "original sin" from "original guilt." AA implies that the disordered actions of the alcoholic, even if springing from an inherited or longstanding biological condition, are not morally blameworthy because they were done without consent and sometimes even without knowledge. Thus, AA members like to remind themselves that they are not bad people getting good, but sick people getting well. This is similar, theologically, to the distinction between material and formal guilt. Material guilt simply points to the actuality of wrongful action. An action is not truly sinful - thus qualifying as "formal" guilt - unless the person did it deliberately, consciously and voluntarily. This nuanced position should be reconsidered by Protestants struggling to understand addiction, for it effectively counters the moralistic (Pelagian) position that is often encountered in discussions of addiction, i.e., that wrongdoing is freely chosen and deliberate.

This also changes how much recovering persons can expect from themselves. Early AAs were driven to despair by the high expectations that motivated the Groupers. They desperately wanted change and were willing to work hard to achieve it, but early AA had more limited expectations, even from God. Their more slow-paced, realistic expectations of change and healing fit better with a reformed Protestant view that perfection cannot be fully achieved in this life (but will be in the next). It is a turn away from the kind of "instant" sanctification expected by Groupers.

\section{Mutually Beneficial Conversations Needed}

From all this, we can see that the concepts of sin and disease are not such opposites to each other, theologically, as many believe. Understanding this can open the door to productive, mutually beneficial, conversations between theologians, religious believers, and recovering persons. It may be especially helpful for those persons falling in two or even three of these categories simultaneously. In fact, one would hope these persons would lead the way in a mutual rethinking of sin, self-will, evil, and the problem of addiction. Indeed, the sin/salvation paradigm within Protestantism has ample room within it for a sickness/healing, or addiction/recovery paradigm. Metaphors of illness and health have never been antithetical to discussions of sin and salvation. Similar to the AA slogan that "I'm not a bad person getting good, but a sick person getting well," church people are often told that the church is not a community for the perfect, but instead a "hospital" for "sin-sick souls." Additionally, as we have seen, the disease concept of addiction and goal of recovery, as propounded by early AA, has many similarities to the Oxford Group's view of sin and salvation. 
From a Protestant theological perspective, we only recognize sin "over our shoulder," i.e., from the position of having experienced and acknowledged grace. Similarly, addiction, too, is best seen and understood from the standpoint of sobriety. From a Christian perspective, God's grace is prevenient, that is, it precedes, inspires, motivates and insures human change. Grace is ultimately the presence of God, rather than spiritual power, energy or reward. While AA may not go this far, both the 12 Step approach and Christianity trust in a power greater than oneself, rather than in simple human effort.

There are a range of views taken within Protestantism on how much human cooperation is needed, and how permanent the change can be. The Protestant Oxford Group-believers in a form of "instant" sanctification and trust in God's power to insure continuance, given human acceptance of this gracetook one stand, while early AA seems, theologically, to have taken another. Similar to those Protestant traditions where one can "lose one's salvation" by committing any number of behaviors proscribed by one's particular group, AA is clear about the perpetual danger of relapse and the inevitable progression of the disease, even for the recovering person. Being "only one drink away from a drunk" is a warning too dire to be ignored.

However, this is different from the Christian affirmation that "nothing can separate you from the love of God." It is different, too, from the doctrine of "election"-even though heard as offensively exclusivist today - which affirms that no manner of slippage or sin could take away one's salvation. This doctrine, effective in its day, was meant to reassure believers that God has already taken this possibility into account and is always ready to welcome back the repentant. While AA might seem to lean toward the theologically pessimistic (that one can lose one's recovery), in practice recovery groups emulate the more positive view, endlessly welcoming back those who have "fallen off the wagon" but return to try again. Although the word grace might not often be heard, the endless re-welcoming of those who slip is similar, as is the experience of acceptance and forgiveness. Still, grace has a limited shelf-life in the addiction recovery paradigm, ever needing upkeep. Continued meeting attendance, forever identifying oneself as an alcoholic, telling one's story, reaching out to other alcoholics, availing oneself of a sponsor and group support, all these are seen as life-long necessities if one wants to "keep" one's recovery.

\section{Conclusions}

The Oxford Group and early AA agreed on many things: a transcendent active God, group support, the value of experience over theory, the unflinching identification of human failings, the need for recognition, confession and amends. Both felt they were not to be identified with organized religion, instead seeing themselves as set apart, not beholden nor responsible to religious structures. Most significantly, both agreed that human self-centeredness or over-self-reliance was the heart of the problem. Both were willing to drop everything to help a person in need. Both relied on group support, personal attention, and mentoring.

However, as we have seen, early AA was not simply a copy of Oxford Group theology. Their success in treating alcoholics differently suggests an implicit theological retrofit. Where the Oxford Group, like much traditional Christianity, understood all human nature to be warped by sin, early AA members moved away from this view. By separating out one group of individuals because of their particular problem, they laid the cornerstone of the contemporary recovery landscape of different groups for different problems. Although their diagnosis of the problem of alcoholism sounded a lot like the sin idea 
in the Oxford Group, early AA often restricted this "defect of character" to a specific group of sufferers. And yet, in an ironic twist, the resultant spread of the addiction metaphor to cover greater and greater areas of life's inevitable difficulties suggests a cultural reinvention of a type of universal explanation for human dysfunction, even approaching in its wide scope the older idea of sin.

The Oxford Group was supremely confident that conversion and regeneration could happen fully and speedily, and that it could open the way for God to work miracles on a daily basis. For Groupers, no one was exempt from this good news. While they took sin very seriously, they took grace even more seriously. The will changed by divine grace is what made their perfectionistic expectations possible. AA was much more realistic about the pace of change which alcoholics could expect. Although it offers high goals and the removal of "all defects of character," in practice even sobriety does not guarantee complete change, for one is always recovering.

When carefully analyzed it becomes clear that the addiction recovery model is also a critique and a challenge to popular ideas of the Christian doctrine of sin. For the AA model implicitly challenges the moralistic interpretation of dysfunctional behavior that has become the common misconception of the sin concept. Perhaps that is why the addiction model has become - in many ways - a replacement metaphor for behaviors once clearly labeled by many religious people as sin.

From the perspective of critique, Protestantism has much to learn from AA. Besides avoiding moralism, the 12 Step approach also reintroduces an idea of human frailty that has some fascinating similarities to the idea of original sin. It unknowingly calls us back to a deeper understanding of human powerlessness in the face of sin and evil, as well as to our need for the intervention of divine grace. But the recovery movement also stands against the wider culture's rejection both of moral fault and of the unavoidable human inclination to turn from God (that is, sin).

Protestant theologians as well as lay believers would benefit from dialogue with persons grappling with a difficult problem like addiction. For AA and other recovery groups have posed the problem and the solution in a way that is amenable to Christian categories, while also critiquing them. Given AA's roots in the Oxford Group, this should not be surprising. The dialogue, however, is short-circuited when AA is perceived simply as an anonymous reflection of the Christian message or something entirely different. Instead, a theological analysis of AA offers deeper contributions and challenges.

Many issues raised by the addiction problem are relevant to theology and to lived faith. Ultimately, we are dealing with the human condition, its vulnerabilities, limitations, potentials and ends. Though the defined focus of AA is pragmatic, many dedicated and long-term members realize they are not simply dealing with behavior modification or physiology. They understand they are grappling with issues ultimately spiritual in nature. The AA model raises again such crucial theological issues such as original sin versus original guilt, the bondage of the will, human finitude, the "imago dei" (image of God in humans), human responsibility, the power of community, and the potential of grace to change humans for the better.

Thus, the sin and addiction concepts have many things in common. Like addiction, sin feels hopeless and trapping. We are introduced to it before we are even self-aware, we copy it from others, we contribute to it before we even know what we are doing, we quickly fall into the habit of acquiescing and then do not easily change. Both sin and addiction create a downward spiral from which it is very hard to extricate oneself. The good news is also common to both ways of looking at human dysfunction, that is, there is a power greater than ourselves who can lift us off this slippery slope and truly transform 
us. The good news is that grace works to fully restore our humanity. We can legitimately expect more of life, even though we will battle sin continually. Whether it is addiction or any other type of human dysfunction, the results are alienation, lack of human flourishing, and self-loss. To recover takes divine grace, and this route promises restoration to the human fullness for which everyone longs.

\section{Conflicts of Interest}

The authors declare no conflict of interest.

\section{References and Notes}

1. Linda A. Mercadante. Belief without Borders: Inside the Minds of the Spiritual but not Religious. New York: Oxford University Press, 2014.

2. Linda A. Mercadante. "For an earlier approach." In Victims \& Sinners: Spiritual Roots of Addiction and Recovery. Louisville: Westminster John Knox Press, 1996.

3. When connections are made from the side of the recovery movement, rarely are conceptual elements highlighted and when they are, the rejected concepts are often what is stressed. Even noted historian of AA, Ernest Kurtz, in his Not God: A History of Alcoholics Anonymous. Center City, MN: Hazelden Foundation, 1979 who otherwise gives excellent coverage of the Oxford Group connections, does not dwell on the conceptual similarities. However, a minority perspective makes an effort to highlight the connections. See, e.g., Dick Burns. The Oxford Group and Alcoholics Anonymous: The AA-Good Book Connection. Seattle: Glen Abbey Books, 1992 or Dennis Morreim. "A Theological/Biblical Perspective of the Twelve Steps of Alcoholics for Implementation in Ministry.” D. Min. Thesis, Luther Northwestern Theological Seminary, St. Paul, MN, 1984. More recently, there are some contemporary self-help books, such as Stephen Aterburn and David Stoop. The Life Recovery Workbook: A Christian Guide through the 12 Steps. Tyndale House, 2007 and groups, such as Celebrate Recovery, which try to Christianize or prove the Christian undertones of the program.

4. Geoffrey Williamson. Inside Buchmanism: An Independent Inquiry into the Oxford Group Movement and Moral Re-Armament, London: Watts \& Co., 1954.

5. For a general sense of Buchman's approach, see Frank Buchman. Remaking the World: The Speeches of Frank N.C. Buchman. London: Blandford, 1947.

6. Howard Arnold Walter. Soul-Surgery: Some Thoughts on Incisive Personal Work. Calcutta: Association Press, 1919.

7. Arthur J. Russell. For Sinners Only. London: Hodder \& Stoughton, 1932.

8. Allan W. Eisler. Drawing-Room Conversion: A Sociological Account of the Oxford Group Movement. Durham, N.C.: Duke University Press, 1950.

9. Laurence William Grensted. What is the Oxford Group? London: Oxford University Press, 1933.

10. Walter Houston Clark. The Oxford Group: Its History and Significance. New York: Bookman Associates, 1951.

11. Mercadante, Victims \& Sinners: Spiritual Roots of Addiction and Recovery includes a close reading of The Big Book. 
12. See "Bill's Story" in the Big Book, p. 13: "I ruthlessly faced my sins." See also his comment that the Big Book "reeks of sin, sickness, and death," Letter, 1950, quoted in As Bill Sees It. New York: AA World Services, 1991, p. 116.

13. Alcoholics Anonymous: How Thousands of Men and Women Have Recovered from Alcoholism [The Big Book], 4th ed. New York: Alcoholics Anonymous World Services, Inc., 2001, p. 58.

(C) 2015 by the author; licensee MDPI, Basel, Switzerland. This article is an open access article distributed under the terms and conditions of the Creative Commons Attribution license (http://creativecommons.org/licenses/by/4.0/). 